Research, part of a Special Feature on Public policies and management of rural forests: lasting alliance or fool's dialogue?

\title{
Are Local People Conservationists? Analysis of Transition Dynamics from Agroforests to Monoculture Plantations in Indonesia
}

\author{
Laurène Feintrenie $^{1,2}$ Stefan Schwarze $^{3}$, and Patrice Levang ${ }^{4,5}$
}

\begin{abstract}
Cash crops are developing in the once forested areas of Indonesia in parallel with market and economic improvements. Perennial crops such as coffee, cocoa, and rubber were first planted in estates by private or public companies. Local people then integrated these crops into their farming systems, often through the planting of agroforests, that is, intercropping the new cash crop with upland rice and food crops. The crop was generally mixed with fruit trees, timber, and other useful plants. A geographic specialization occurred, driven by biophysical constraints and market opportunities, with expansion of cocoa in Sulawesi, coffee in Lampung, and natural rubber in eastern Sumatra. However, during the past three decades, these agroforests have increasingly been converted into more productive monoculture plantations. A common trajectory can be observed in agricultural landscapes dominated by a perennial cash crop: from ladang to agroforests, and then to monoculture plantations. This process combines agricultural expansion at the expense of natural forests and specialization of the land cover at the expense of biodiversity and wildlife habitats. We determined the main drivers of agricultural expansion and intensification in three regions of Indonesia based on perception surveys and land use profitability analysis. When the national and international contexts clearly influence farmers' decisions, local people appear very responsive to economic opportunities. They do not hesitate to change their livelihood system if it can increase their income. Their cultural or sentimental attachment to the forest is not sufficient to prevent forest conversion.
\end{abstract}

Key Words: agrarian transition; agricultural intensification; agroforestry; cocoa; coffee; cropping trajectory; Indonesia; oil palm; rubber

\section{INTRODUCTION}

Slash-and-burn cropping systems use fire to clean and clear a plot that will be cropped for two to five years. After several years of cultivation, soil fertility declines and weeds overwhelm the crop, forcing the farmer to abandon the plot to a bush fallow for 15 to 20 years. In Asia, authorities have strongly opposed such swidden systems, suggesting they are the main cause of deforestation. Findings from the Alternatives to Slash and Burn Programme (Van Noordwijk et al. 1995) and other scientific research (Angelsen 1995) refute this accusation. In fact, the main limitation of slash-and-burn agriculture is its low cropping intensity. An increase in demographic pressure directly induces the intensification of the system through the reduction of fallow length; direct consequences of this are reduced forest regrowth and biomass regeneration, which are both essential for fertilizing the plot through slash and burn. With an appropriate fallow time, slash-and-burn practices can be sustainable, can respect both forest biodiversity and ecological functions, and can provide livelihoods. However, this requires space and low population densities, which are increasingly rare conditions (Cramb et al. 2009). Upland rice cultivation in a slash-and-burn system is common in Indonesia. The Indonesian term "ladang" refers either to the cropping system as a whole or to a plot of upland rice being cultivated for one to three years.

In several regions of Indonesia, as in other countries, ladang have been converted into agroforests. The broadest definitions of agroforestry describe it as the combination of trees with annual or perennial 
crops, and/or livestock, in space or time, as a means to produce food and to generate cash income (Nair 1985, Torquebiau 2000). Agroforests have been defined as complex agroforestry systems that combine trees with other crops and spontaneous growth, in a forest-like structure (Huxley 1999). Indonesian agroforests have often been presented as models of sustainable cropping systems (Torquebiau 1992, Dove 1993, De Foresta 1994, Levang 1994, Huxley 1999, Michon 2005, De Foresta 2008). They have served as a reference point in agriculture, especially through the association of cultural values and conservation of the natural environment.

More recently, an increasing number of studies have reported the growing disappearance of agroforests (Joshi et al. 2002, Rasul et al. 2004, Ashley et al. 2006, Feintrenie and Levang 2009, Garcia et al. 2010). Several causes are often cited to explain this trend of intensification of agriculture, which in Southeast Asia is combined with agricultural expansion on forested land (De Koninck 2005). Included among these causes is the frequent claim that the integration of national economies into international markets is being imposed on local populations. Following the neoliberal policies promoted by the International Monetary Fund, Indonesia has to some extent developed its national economy based on exports, and on promoting mining, logging, and export cash crops (Barlow and Drabble 1990, Casson 2002, Keesler et al. 2007, McCarthy 2007).

Another cause of the ongoing intensification of agriculture in Indonesia is the decentralization of governance that began in 1999. This shift introduced a dispersal of responsibilities for forests to lower levels of governance, but land tenure and forest status remain unclear in both the legislation and the field (Legowo and Takahashi 2003, Barr et al. 2006). Since the implementation of decentralization, districts and provinces have benefited from the income generated by agriculture in their territory, and thus often favor agricultural production. The direct popular elections of the legislative and executive bodies at national, provincial, and district levels give the people a say in the policies to be implemented. Furthermore, since the end of Suharto's regime, people no longer hesitate to organize strikes and demonstrations, and they feel more involved in political decision-making (Feintrenie and Levang 2010). However, reports of abuses by agribusiness companies and conflicts related to land grabbing, market conditions, or local governance still abound (Colfer and Resosudarmo 2002, Colchester et al. 2006, Adnan and Yentirizal 2007, Suyanto 2007). Such negative reports are characteristic of the development of boom crops in Indonesia (Belsky and Siebert 2003, Ruf and Schroth 2004, Rist et al. 2010). Crops such as oil palm, cocoa, and rubber developed quickly due to the involvement of actors from a range of sectors: governments at various levels, agribusinesses, local communities, and migrants (government-sponsored through the transmigration program or spontaneous and independent migrants).

In locations where such plantations are increasingly replacing forests and agroforests, questions arise regarding local people's involvement in their region's economic development. Are local people deliberately following a path toward agricultural expansion and intensification, or are they the innocent victims of economic globalization? The objectives of this study are to analyze farmers' perceptions of various land uses and agroforests and forest conservation, and to identify the factors that influence their decisions regarding land uses. We assume that Indonesian farmers are the main decision-makers regarding the use of their lands, but they are not isolated, and economic, social, and political stakeholders and contexts influence their decisions. Their choices are driven by economic, cultural, and sentimental considerations, as well as by technical constraints and opportunities.

To assess the participation of local communities in landscape changes toward monoculture plantations, we selected three regions in Indonesia that have seen the development of different challenger crops. We define challenger crop as the boom crop that arrived most recently in the area and that is competing for land with former traditional systems. Building on our knowledge of the sites, we interviewed villagers about their plantations and how they make choices about plantations; we also compared the profitability of various land uses.

\section{STUDY CASES}

In the first case, Bungo district in the province of Jambi, rubber cultivation has developed since the 1920s with very positive impacts on livelihoods. However, with growing pressure on land during the past 30 years (Bonnart 2008, Ekadinata and Vincent 2010), rubber agroforests are increasingly being 
converted into monoculture rubber plantations. More recently, oil palm has emerged as the new challenger for agroforests (Chong 2008, Feintrenie et al. 2010). In 2010, the main land uses on dry lands are rubber agroforests, rubber monoculture plantations, and oil palm plantations. Some upland rice cultivation is still present in the most remote areas of the district, and lowland rice is cultivated along some rivers. This area has very few terraces for irrigated rice cultivation, and many villages have stopped cropping inundated rice to work only in their cash crop plantations, which are more profitable. Some rice paddies have been converted into rubber or oil palm; others have been left fallow and may revert to rice cultivation whenever there is a need for food (such as during the 2008 economic crisis, when rubber and palm oil prices dropped and rice temporarily became an attractive alternative to the main cash crops). Oil palm was first developed in the district by medium-scale companies that were participating in transmigration programs; later, locals and migrants started planting it on independent small holdings (Feintrenie et al. 2010). In the survey, we compared the main land uses: rubber agroforests, rubber monoculture plantations, and oil palm plantations. None of these crops presents strong seasonality.

The second case is the region of Pesisir, in the province of Lampung. The mountain range of Bukit Barisan borders the Indian Ocean, and flatlands are limited to a narrow littoral of beaches and rice paddies. Behind the littoral, the rice paddies give way to damar agroforests, which span from the piedmont to the limits of Bukit Barisan Selatan National Park (and beyond). Damar is the name of both a tree (Shorea javanica, Dipterocarpaceae) and the resin extracted from the tree. The resin is a main component in the processing of incense, paint, and varnish. The tree can grow to more than $40 \mathrm{~m}$ in height. Damar agroforests are established at the expense of the primary forest by a typical slash-andburn system. The young Shorea seedlings are intercropped with upland rice and vegetables during the first two years. Coffee and/or pepper vine take over from the third to tenth years. The relay is then taken by various fruit trees, and the first damar harvest does not occur until around 20 years after planting (Michon 1985, Mary 1986). Thus, it is commonly said that farmers plant damar for their children and grandchildren (Amsallem 1994). The resin of mature damar agroforests is harvested every three to five weeks, and there is no strong seasonality. Farmers frequently complain about theft of resin, especially in areas close to the villages (Kusters et al. 2008). These agroforests have long resisted the expansion of more profitable crops such as coffee, cocoa, and oil palm, and somehow maintain a kind of buffer zone around the national park. Recently, however, in some areas, coffee has become the main crop of the system (Kusters et al. 2008), damar trees being planted more as land markers than for resin production. The latest observed trend consists of the conversion of old damar agroforests and forests into cocoa and oil palm plantations.

The third case, the Lore Lindu region, is located about $50 \mathrm{~km}$ south of Palu, the capital of Central Sulawesi province. At the heart of the region is the Lore Lindu National Park, which was established in 1983 to protect its unique flora and fauna (Shohibuddin 2008). The mountainous region covers an area of $7257 \mathrm{~km}^{2}$ and is characterized by strong differences in environmental conditions. The altitude ranges from just above sea level to $2600 \mathrm{~m}$ and rainfall varies from 500 to $2500 \mathrm{~mm}$ per year (Maertens et al. 2006, Erasmi and Priess 2007). Land use in the area is characterized by a strong lowland-upland dichotomy. In the valleys, mainly paddy rice is grown, whereas the uplands are dominated by dry rice and perennial crops (Maertens et al. 2006). Traditionally, most of the uplands were used for slash-and-burn cultivation of food crops such as upland rice, corn, and cassava. Coffee, which was originally introduced by the Dutch colonial power, was the main cash crop in the uplands (Weber 2006). Since the 1980s, land use in the uplands has changed drastically with the introduction of cocoa by Bugis migrants (Ruf 2001). The cocoa acreage has increased from almost 0 ha in the 1980s to more than 20,000 ha in 2007 (Reetz 2008). Cocoa agroforests have been established on former forested land, which was often used for slash-and-burn agriculture, and by replacing coffee (Juhrbandt et al. 2010). Although during the 1980s most cocoa was grown under a diverse set of natural shade trees, more and more plantations have been established with almost no shade trees (Reetz 2008). In the analysis, we compared the main land use systems that characterize the process of land use change: upland rice, cocoa agroforests with a diverse set of natural shade trees, and cocoa plantations with almost no shade tree cover. 


\section{METHODS}

Each of the authors has extensive experience in at least one of the study sites, which has included long stays in the villages and in-depth interviews with villagers and other actors. In each site, we selected a sample of nine to 12 villages, which differ in distance to the forest, intensification of agricultural practices, and remoteness (Fig. 1).

We conducted individual interviews with about 30 farmers in each village, with a balanced sample of respondents according to age and gender; this gave us a total of 802 respondents. Interview questions covered the drawbacks and merits of each type of plantation crop in the village, the pros and cons of agroforestry systems compared with monocultures, and the farmers' perceptions about their village landscape at present and in the coming 20 years. For this last question, a tangible tool was used to help the respondents estimate the percentage share of forests, agroforests, and plantations in the total village area. Questions about the pros and cons of plantations and agroforests included a choice of factors related to technical and economic as well as cultural, religious, and more sentimental aspects. The list of factors was developed during group discussions in Jambi, and was later adapted for the two other sites. However, respondents could always add new factors to the list. We also asked respondents to choose and rank the five most determining pros and cons for each type of land use, and to list the advantages and drawbacks of mixed tree plantations versus monocultures. A score was attributed to each factor according to its rank in the selection. The factors were later grouped into four categories (cultural, sentimental, technical, economic) for analytical purposes.

To complete the analysis, we compiled data on land use profitability from former studies conducted at each site, and updated them using recent field survey data (prices and labor needs).

\section{RESULTS}

In response to questions about the pros and cons of mixed-tree systems compared with monoculture plantations, farmers first pointed out technical factors such as labor needs, length of immature period, sensitivity to pests, working conditions, and management skills needed (Fig. 2). Technical factors were the most important aspect in choosing between monoculture and agroforestry, with farmers referring both to technical constraints and to the advantages of agroforests. Limited profitability of mixed-tree systems was stated as a major constraint, especially in Jambi; in Sulawesi and Lampung, sentimental and cultural attachments to the traditional agroforests were cited as positive factors influencing their conservation.

Fig. 3 shows the most determining factors for farmers in the choice of a plantation. Some variability may be observed between the three sites. In Sulawesi, villagers cited fuelwood as a major secondary product of cocoa plantations. They plant Gliricidia trees between the young cocoa trees; after a few years, they remove them for use as fuelwood. Also in Lore Lindu, plantations are established mainly on secondary forest, whereas in the two other sites, they replace agroforests or bush fallows. Easy commercialization of the product was stated as being most important in Lampung and Sulawesi, and the absence of seasonality in the harvest was most important in Lampung. The absence of a secure and competitive market for some products (cocoa and oil palm in Lampung, coffee in Sulawesi) may hinder locally the expansion of the crop. By contrast, the existence of a well-established and competitive marketing system, such as for cocoa in Sulawesi and for both rubber and oil palm in Jambi, has fostered expansion. The absence of seasonality in the two main commodities of Jambi explains why respondents did not cite these as determining factors in the switch from agroforests to monocultures. Another factor not included in Fig. 3 because of its specificity to Lampung is theft of damar resin, ranked third among the drawbacks of agroforests.

The economic results of a plantation were clearly described as a major determinant of farmers' decisions. The comparison of the profitability of the investigated land use systems confirms and explains farmers' choices of challenger crops. Net returns to land and labor, illustrated in Fig. 4 according to variability in farm gate prices, are considerably higher in monocultures than in agroforests, even when taking into account secondary products. Net returns to land for the average prices of the main commodities are about $€ 2300 /$ ha for rubber monoculture in Jambi compared with $€ 1000 /$ ha for rubber agroforest; about $€ 2700 /$ ha for cocoa monoculture in Sulawesi compared with less than 
Fig. 1. Location of the three study sites in Indonesia.

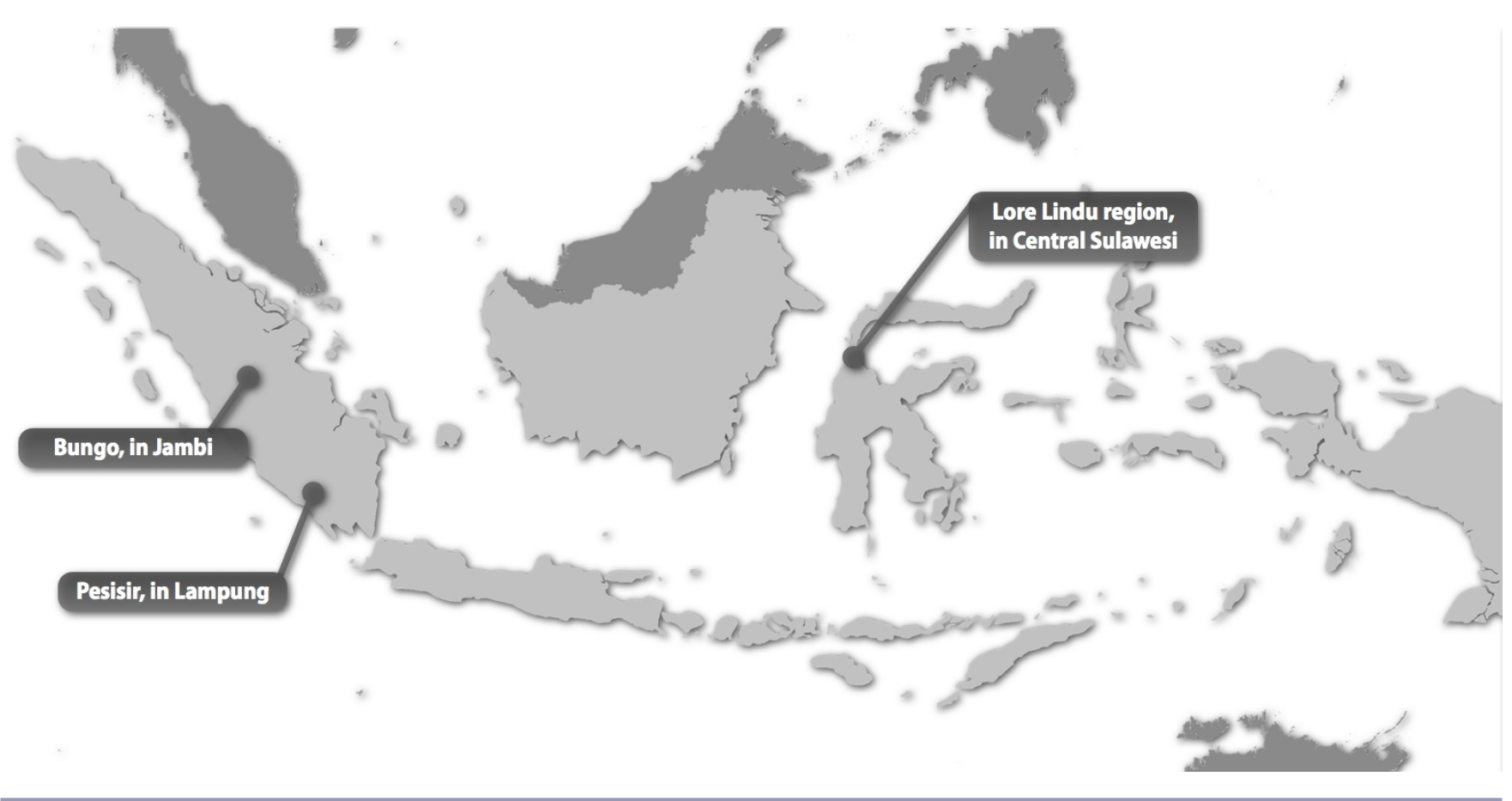

$€ 200 /$ ha for cocoa agroforest; and about $€ 1000 /$ ha for coffee in Lampung compared with less than $€ 500 /$ ha for damar agroforest. In Jambi, rubber and oil palm are both highly profitable; net return to land is on average higher for rubber monoculture than for oil palm ( $€ 1600 / \mathrm{ha}$ ), but net return to labor of oil palm is higher with an average of $€ 27 /$ personday, compared with $€ 13 /$ person-day for rubber monoculture. With lower labor spending on fertilizing and weeding, rubber agroforest has a slightly higher return to labor than rubber monoculture. However, this does not include the time to travel to the plot: usually agroforests are cropped in remote areas, whereas monocultures are planted near roads, meaning that, including traveling time, agroforests have a smaller return to labor.

All the above results are well supported by the last part of the perception survey where respondents were asked to predict the land use evolution in their village. Fig. 5 shows people's perception of their landscape. In Bungo, farmers predict a major shift toward monocultures but expect a half-half share between rubber and oil palm. They do not foresee that more than $15 \%$ of agroforests will remain in 20 years (Therville 2008, Therville et al. 2010). The arrow for Lampung is nearly horizontal, which indicates a quite stable proportion of damar agroforests, and a move toward more cocoa and oil palm and less coffee. In the Lore Lindu region, the main trend that farmers predict is an increase in cocoa plantations. They expect that the trend of the past decades - a reduction in slash-and-burn and cocoa agroforest area and an increase in cocoa plantations - will continue in the next 20 years. As shown by the bar chart in Fig. 5, most of the respondents say they are pleased about the expected land cover change they described.

These land uses might change over time because they depend heavily on market opportunities at the local level. Nevertheless, the profitability of exported cash crops is directly linked to the international market, where the commodity prices are determined. Fig. 6 shows the evolution of the world market prices for rubber, palm oil, cocoa, and coffee, expressed in Indonesian rupiah per 
Fig. 2. Pros and cons of agroforests compared with monoculture plantations (results of the perception survey) (adapted from Therville 2008). "Cultural arguments" includes inheritance from grandparents, staple food production, and daily domestic consumption products. "Sentimental attachment" includes attractive scenery and site of usual daily work. "Economic results" includes low costs of plantation and production, high return to land, easy commercialization, stable and high price of the commodity, and long production period. "Technical advantages" or "constraints" includes resistance to pests, low labor requirements, wide variety of products, no seasonality, tree cover that protects workers against sun and rain, protection of soil fertility and erosion prevention, and trees that live longer and can be replaced one by one.
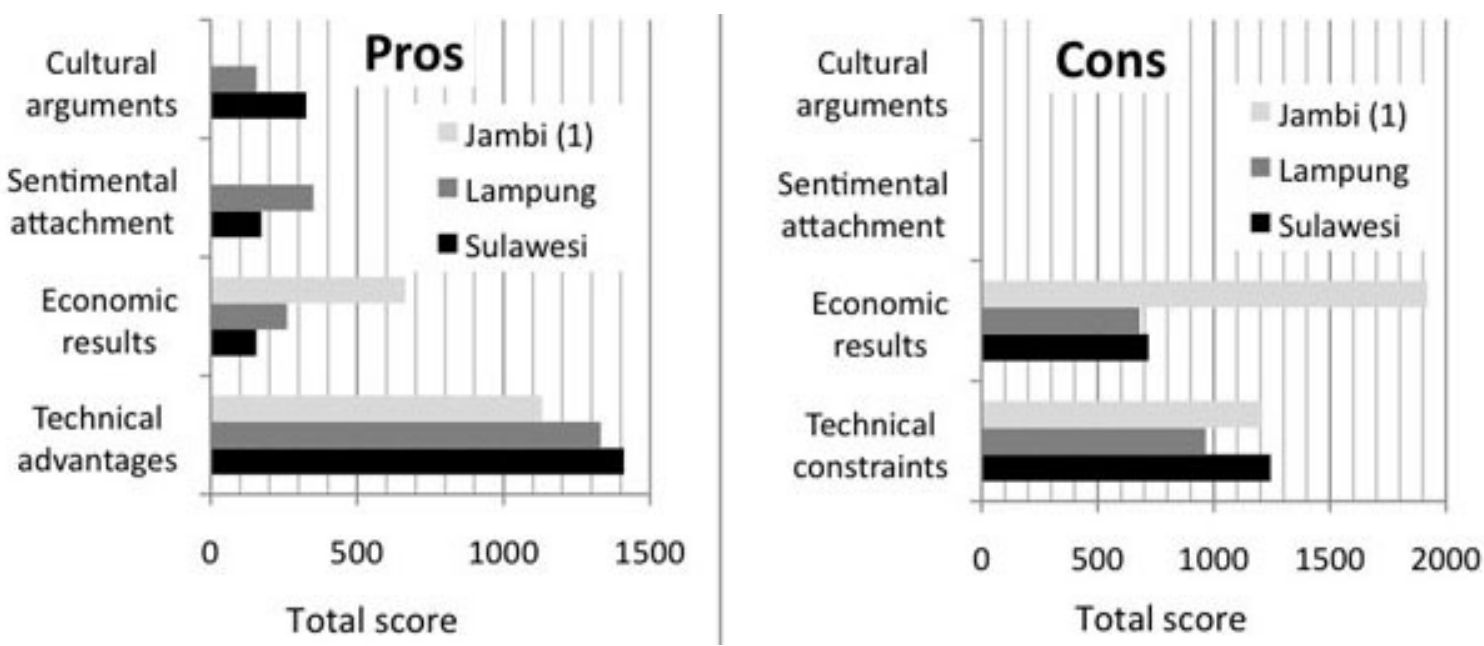

kilogram. In general, prices for the four commodities fell from 1997 to 2001. After 2001, prices recovered quickly and peaked in July 2007. The international economic crisis of 2008 saw most export commodity prices plummet. Cocoa and rubber prices have been increasing since the 2008 price slump, but palm oil and coffee have not yet recovered their previous levels. Nonetheless, palm oil appears to have been the most stable commodity over the past 15 years.

\section{DISCUSSION}

There is growing consensus among scientists that the low profitability of agroforests compared with challenger crops is a major hindrance to their conservation (Belcher et al. 2004, Maertens et al. 2006, Feintrenie et al. 2010, Lehébel-Péron et al. 2010, Therville et al. 2010). Our results confirm that economic factors are the first or second main drivers of agricultural intensification. Technical concerns came first in Sulawesi and Lampung, and second in Jambi, with both pros and cons for agroforestry practices. To increase the productivity of agroforests, different options have been researched. Some results appear to be positive from a technical point of view, such as the introduction of highquality clones of rubber in agroforests (Penot 1995, Penot 1998). But whenever smallholders are asked to use expensive inputs such as high-quality seedlings or fertilizers, they are reluctant to maintain agroforestry practices - even though these inputs are given freely to farmers - and prefer monoculture plantations to get the highest benefits they can (Penot 2000, Levang and Sitorus 2006, Maertens et al. 2006, Seeberg-Elverfeldt et al. 2009). Our results demonstrate that farmers are looking first of all for a profitable crop with high productivity, low labor needs, and short immature period. What they favor the most is a fast and high return to labor. Their second concern relates to securing a regular income (weekly or monthly) generated by their plantations, with few costs incurred and low financial risk. 
Fig. 3. Farmers' reasons for choosing a perennial crop (responses to perception survey) (adapted from Therville 2008). These are the reasons farmers most often gave for their choice of crop among oil palm, rubber, cocoa, and coffee. These arguments are linked more to the species than to how it is planted in agroforest or in monoculture.

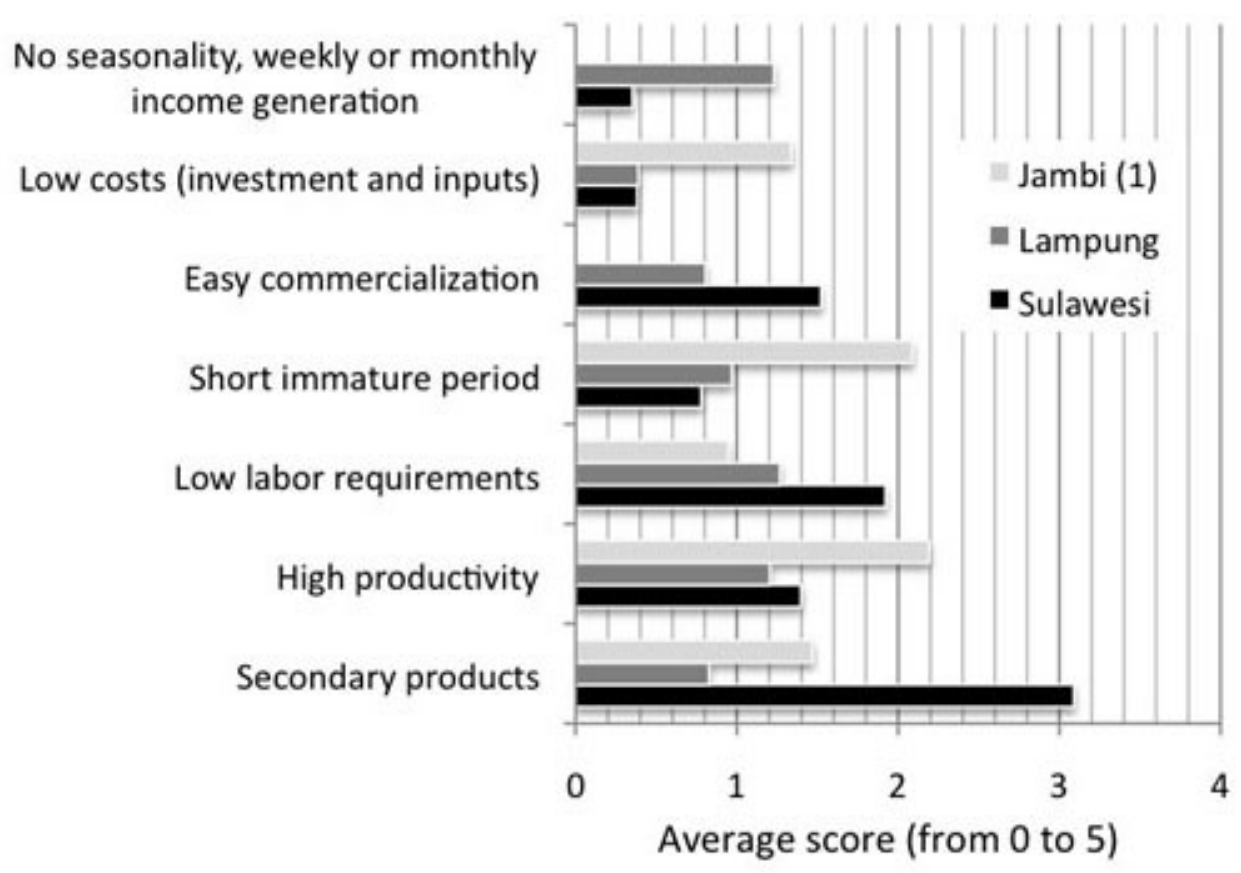

Secondary products add value to a plantation as long as their presence does not reduce the productivity of the main crop. The comparative analysis of the profitability of different land uses proves that the current challenger crops in the three sites - oil palm in Jambi and Lampung, cocoa in Sulawesi and Lampung - are much more profitable than the traditional agroforests and upland rice.

Fluctuations in international prices and exchange rates influence farmers' decisions and can generate a regional boom, as for cocoa in Sulawesi and rubber and oil palm in Sumatra. Indonesian smallholders cope with the price fluctuations of export commodities by combining various cash crops on their farm. The global financial crisis of $2008 \mathrm{did}$ not reduce farmers' confidence in export agricultural commodities but convinced them of the interest to diversify in several cash crops (Feintrenie et al. 2010). To maximize their income, they opt to segregate the different crops into separate plots rather than integrate them in agroforests (Feintrenie et al. 2010). The predicted landscapes drawn by the farmers confirm this preference. The growing international demand for palm oil, both as edible oil and as biofuel, appears to secure the price stability of this commodity (Levang et al. 2008). Although high prices act as a strong incentive to promote the expansion of a crop, Ruf (2001) observed that prices only accelerate the process of migration of cocoa production - or boom - from one region to another. He demonstrated that increasing production costs (such as labor and inputs) and decreasing availability of forested land are major factors contributing to the end of a cocoa boom in one region and the beginning of a new one in another place. As long as suitable forested lands are available in Indonesia, rubber, oil palm, and cocoa will continue to expand. Only a strong political will to protect forests (either primary or secondary), accompanied by actual law enforcement regarding the protection of national parks and protection forests, can limit the deforestation induced by the expansion of highly profitable plantations. 
Fig. 4. Profitability of the main land use systems for lowest, highest, and average farm gate prices in 2008-2009 (exchange rate of 13,500 IDR = $1 €$ ). Sources: (1) Jambi: Adapted from Feintrenie et al. 2010 and complementary data from field survey, (2) Sulawesi: Adapted from Seeberg-Elverfeldt 2008 and complementary data from field survey, (3) Lampung: Personal communication from Yulia Ramah Fitriana 2010, and (4) Lampung: Adapted from Kusters 2009 and complementary data from field survey.
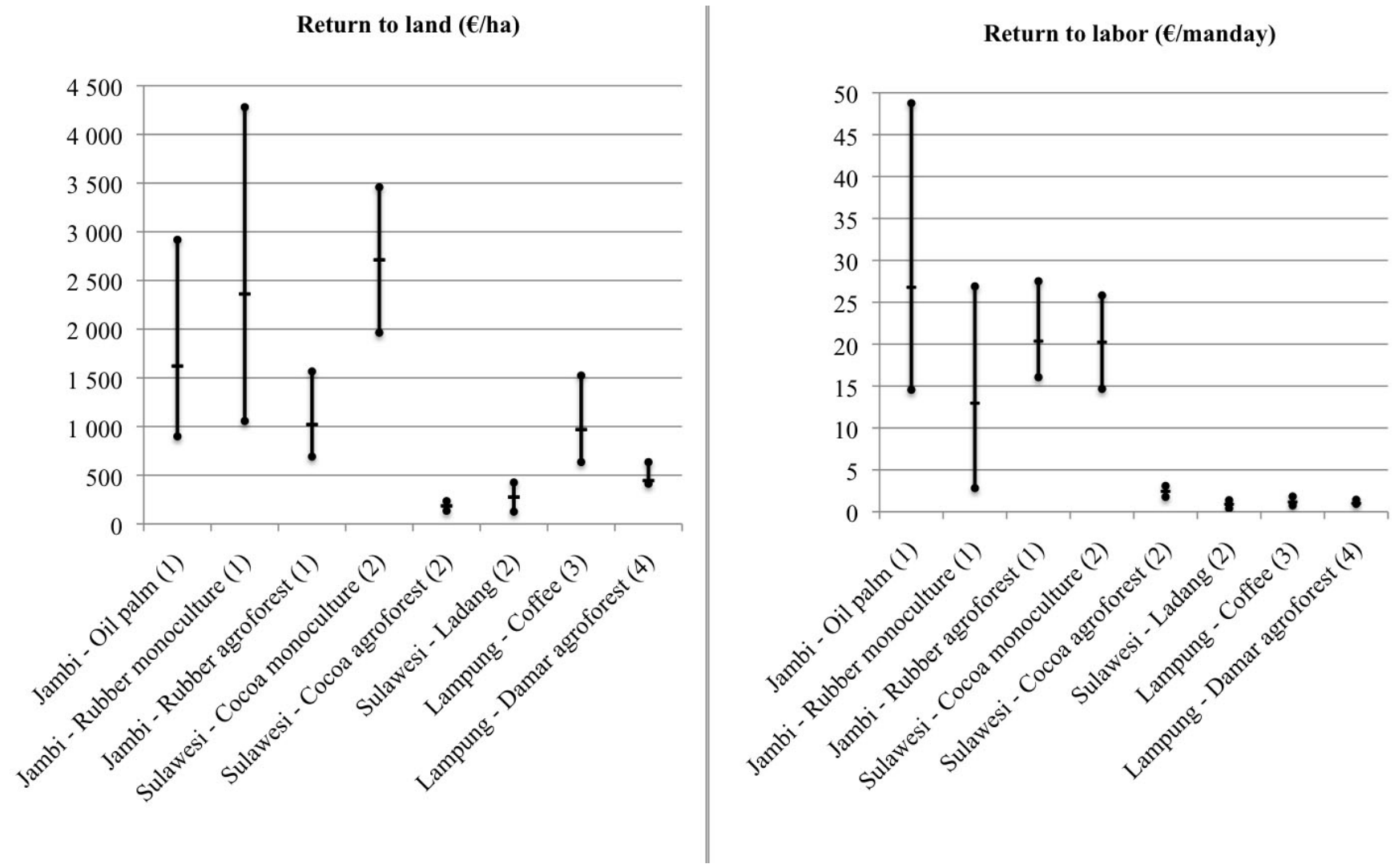

Governments and agribusinesses are often targeted as the main promoters of economic development and are therefore considered accountable for deforestation (Colfer and Resosudarmo 2002, Cunningham et al. 2005). Local communities are then often considered victims of this conversion process (Berkes et al. 2000, Gadgil et al. 2003). Our results, supported by other case studies (Eder 2006, Rigg 2006, Cramb et al. 2009, Garcia et al. 2010), show that the farmers are active and informed actors in agricultural expansion and intensification. Their decisions are driven by economic opportunities. Whatever their sentimental and cultural attachment to the forest and traditional agroforestry practices, farmers strive for a better quality of life and enough cash to send their children to school (Levang et al.
2005). Sentimental attachment to traditional systems is a luxury for rich people. Garcia et al. (2010), for example, observed that in the Western Ghats in India, coffee agroforests were converted to no-shade coffee plantations, and forest patches were conserved only by wealthy people. Cramb et al. (2009) found that in six Asian countries, traditional upland rice systems were converted into agroforests. These agroforests were then either transformed into monoculture plantations or were abandoned. Our results support their argument that the development of cash crops often improves local livelihoods but complete specialization may increase households' vulnerability. The 2008 economic crisis was a reminder of the importance of retaining land for the production of rice, either 
Fig. 5. Illustration of landscape predictions for each site (responses to perception survey) (adapted from Therville 2008). Each point of the triangle represents $100 \%$ of land cover of the traditional forested system (damar agroforest in Lampung, rubber agroforest in Jambi, upland rice in Sulawesi), the intensified traditional crop (rubber monoculture in Jambi, coffee monoculture in Lampung, swidden fallows enriched in cocoa or coffee in Sulawesi), or the challenger crop (oil palm in Jambi, cocoa plus oil palm in Lampung, cocoa monoculture in Sulawesi). The arrows represent the proportions of land cover estimated by the respondents (average of all responses) at present and in 20 years from now. The bar chart illustrates the farmers' feelings in relation to the scenario they predicted; the data are missing for Jambi (not included in Therville's survey).

\section{What will the landscape look like in 20 years?}

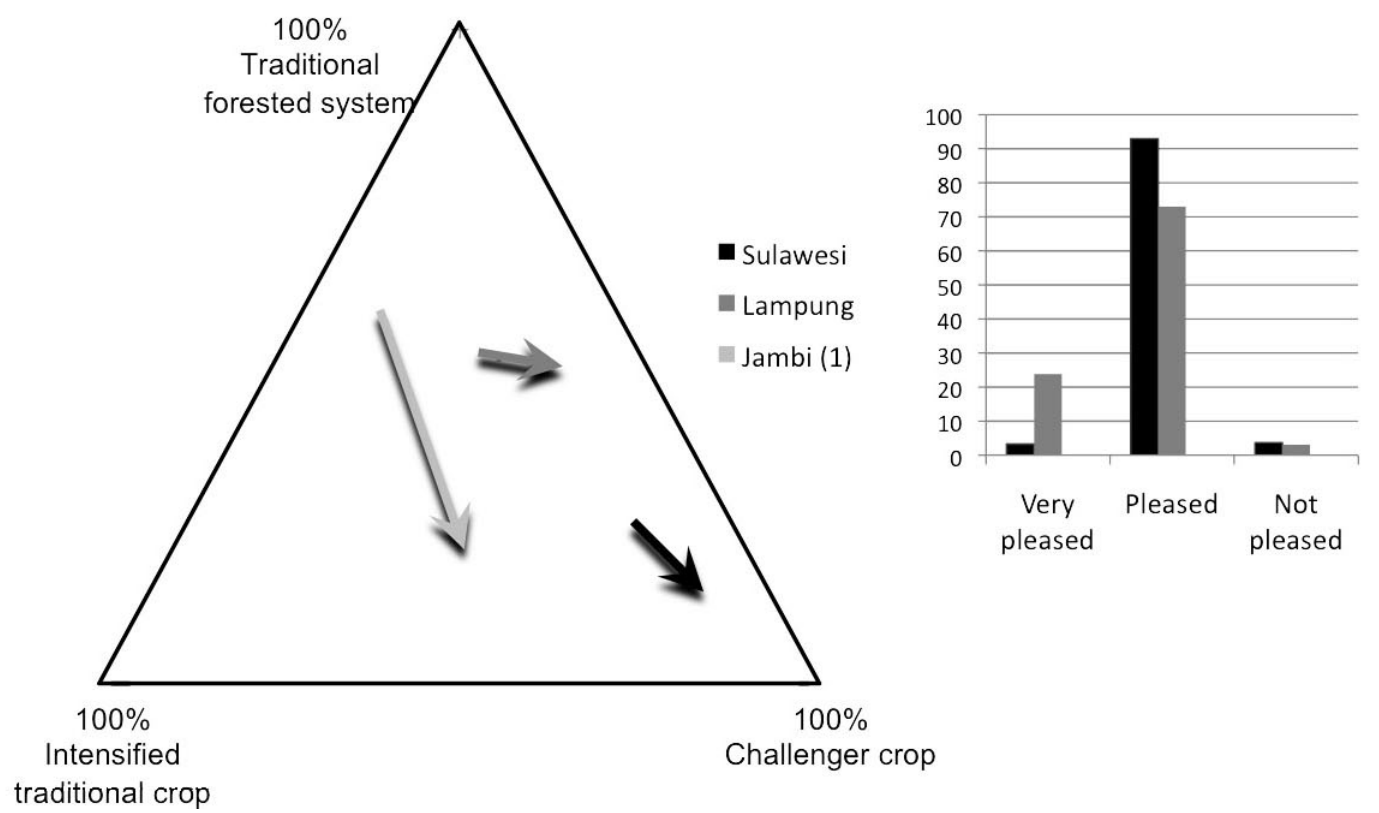

irrigated or dry, as a safety net to cope with low agricultural commodity prices.

Farmers have only a limited range of cash crops to choose from, due both to biophysical constraints of the natural environment and to market opportunities and the priorities set by district and provincial governments. Regional governments may influence local market opportunities through their policies and through the implementation of public programs such as the transmigration program, which involved the agricultural development of a region (Levang 1997), the Indonesian program of rejuvenation of inundated paddy fields, which involved the construction of terraces and irrigation systems (Feintrenie and Martini 2010), or programs that involved the distribution of rubber seedlings in China or Indonesia (Penot 1998, Sturgeon 2010) to promote the development of rubber small holdings

Decentralization means regional governments must attract businesses in order to increase their revenues and to develop their economy. However, the participation of powerful and wealthy companies in a region's economic development creates opportunities for corruption (Dudley 2000, Komarudin et al. 2008, Wells 2008). Moreover, the involvement of agribusinesses usually implies the establishment of large estates, which are landconsuming and a potential source of conflicts with local communities. The unfortunate story of land grabbing by authorities or companies and displaced 
Fig. 6. Evolution of the prices of the main commodities on the international market. Adapted from Index Mundi (2010), based on data from the International Monetary Fund.

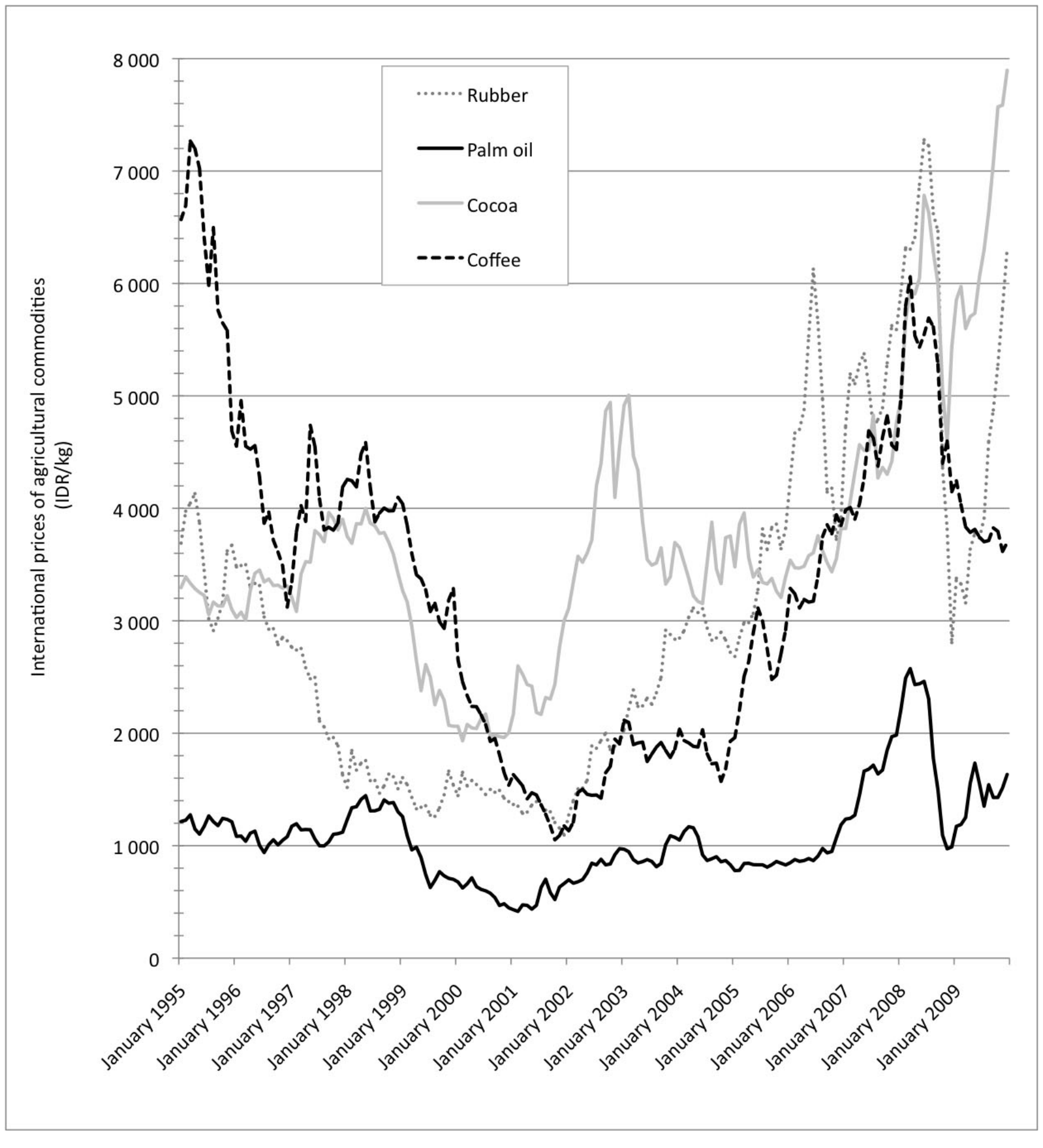


peoples has been repeated far too often (Levang 1997, Hughes 2001, Colchester et al. 2006, Suyanto 2007, Cotula and Vermeulen 2009). Conflicts between companies and communities may also arise over disagreements about the conditions of joint ventures or business partnerships; oil palm development has generated a number of such conflicts (McCarthy 2007, McCarthy and Cramb 2009, Feintrenie et al. 2010). Solutions to avoid such conflicts might lie in smallholder-inclusive development regimes and fairer sharing of benefits among the partners in joint venture schemes (Koh et al. 2009, McCarthy and Cramb 2009, Feintrenie et al. 2010, Sturgeon 2010).

\section{CONCLUSION}

Agroforestry systems - in the broadest definition including swidden cultivation - provide the security of a diversified source of products, usually by combining food crops, cash crops, and various nontimber forest products. They are very resilient to economic and ecological crises and can be considered safety nets for rural households. Another advantage of these systems is their intermediate biophysical characteristics in between forests and plantations, which give them the name "domestic forests" (Michon et al. 2007). However, farmers are far less sensitive to the environmental qualities of their plots; they are more interested in the economic returns as well as the low labor requirements and absence of seasonality. Local people are not conservationists. Payments for carbon sequestration, and more broadly, payments for environmental services, could be used to compensate the lack of profitability of agroforestry systems and to interest smallholders in their conservation.

Given more profitable alternative sources of income, farmers are quick to abandon their traditional systems. A common trend of conversion of agroforests into monoculture plantations is being observed worldwide. Economic globalization promotes the development of export-oriented national policies, which are often based on agricultural commodities. Coffee, cocoa, rubber, and oil palm are defined as boom crops, which developed rapidly in response to the rising international market demand. The enthusiasm that accompanies the rapid expansion of these crops can be explained by their high profitability and the opportunity that they represent for isolated forest people and poor farmers to escape poverty and marginalization. Crop booms are often triggered and boosted by public policies, and they benefit from the financial involvement of big agribusinesses, which leads to the development of infrastructure (such as roads, terracing of steep slopes, and irrigation) in remote areas.

Crop booms may lead to improved livelihoods for local populations, as long as those people are involved in the process and not excluded from the benefits. However, social conflicts may arise when local populations are resettled or displaced so that agribusiness estates, public or private, can be established. For new cash crops - or challenger crops - to have positive impacts on livelihoods, farmers must integrate them into their production system. The development of smallholders' plantations is essential for the participation of local communities. Governments can foster the adoption of new crops by supporting farmers through such means as public extension services.

Responses to this article can be read online at: http://www.ecologyandsociety.org/voll5/iss4/art37/ responses/

\section{Acknowledgments:}

We thank the villagers and other respondents who welcomed us, and the enumerators who helped us in the field: Jhon Roy Sirait, Wiyono, M. Rifcki Aulia, and Sumarno Syamsuri. This study was supported by the project "Integrating Livelihoods and Multiple Biodiversity Values in Landscape Mosaics", a joint research project of the Center for International Forestry Research and the World Agroforestry Centre, with support from the Swiss Agency for Development and Cooperation.

\section{LITERATURE CITED}

Adnan, H., and Yentirizal. 2007. Blessing or misfortune? Locals, transmigrants and collective action. CIFOR Governance Brief June 2007. CIFOR, Bogor, Indonesia.

Amsallem, I. 1994. Les agroforêts à damar (Shorea javanica), Sumatra (Indonésie) - Contribution à l'étude de la croissance des agroforêts et des 
principales espèces ligneuses. Dissertation. CNEARCENGREF, Montpellier, France.

Angelsen, A. 1995. Shifting cultivation and deforestation: a study from Indonesia. World Development 23:1713-1729.

Ashley, R., D. Russel, and B. Shallow. 2006. The policy terrain in protected area landscapes: challenges for agroforestry in integrated landscape conservation. Biodiversity and Conservation 15:663-689.

Barlow, C., and J. Drabble. 1990. Government and the emerging rubber industries in Indonesia and Malaysia, 1900-40. Yale University Press, New Haven, Connecticut, USA.

Barr, C., I. A. P. Resosudarmo, A. Dermawan, J. McCarthy, M. Moeliono, and B. Setiono, editors. 2006. Decentralization of forest administration in Indonesia. Implications for forest sustainability, economic development and community livelihoods. CIFOR, Bogor, Indonesia.

Belcher, B., Rujehan, N. Imang, and R. Achidiawan. 2004. Rattan, rubber, or oil palm: cultural and financial considerations for farmers in Kalimantan. Economic Botany 58:S77-S87.

Belsky, J. M., and S. F. Siebert. 2003. Cultivating cacao: implications of sun-grown cacao on local food security and environmental sustainability. Agriculture and Human Values 20:277-285.

Berkes, F., J. Colding, and C. Folke. 2000. Rediscovery of traditional ecological knowledge as adaptive management. Ecological Applications 10:1251-1262.

Bonnart, X. 2008. Agrarian diagnosis in Bungo district, province of Jambi (Indonesia). Dissertation. IRC/Supagro, Montpellier, France.

Casson, A. 2002. The political economy of Indonesia's oil palm subsector. Pages 221-245 in C. J. P. Colfer and I. A. P. Resosudarmo, editors. Which way forward? People, forests and policy making in Indonesia. Resources for the Future, Washington, D.C., USA.

Chong, W. K. 2008. Oil palm development and land management in Bungo district, Indonesia. Dissertation. IRC/Supagro, Montpellier, France.
Colchester, M., N. Jiwan, Andiko, M. Sirait, A. Y. Firdaus, A. Surambo, and H. Pane. 2006. Promised land. Palm oil and land acquisition in Indonesia: implications for local communities and indigenous peoples. Forest Peoples Programme/ Perkumpulan Sawit Watch, Jakarta, Indonesia.

Colfer, C. J. P., and I. A. P. Resosudarmo, editors. 2002. Which way forward? People, forests and policy making in Indonesia. Resources for the Future, Washington, D.C., USA; CIFOR, Bogor, Indonesia; Institute of Southeast Asian Studies, Singapore.

Cotula, L., and S. Vermeulen. 2009. 'Land grabs' in Africa: can the deals work for development. IIED Briefing September 2009. [online] URL: http://ww w.iied.org/pubs/pdfs/17069IIED.pdf.

Cramb, R. A., C. J. P. Colfer, W. Dressler, P. Laungaramsri, Q. T. Le, E. Mulyoutami, N. L. Peluso, and R. L. Wadley. 2009. Swidden transformations and rural livelihoods in Southeast Asia. Human Ecology 37:323-346.

Cunningham, A., B. Belcher, and B. Campbell, editors. 2005. Carving out a future: forests, livelihoods and the international woodcarving trade. Earthscan, London, UK.

De Foresta, H. 1994. Agroforests in Sumatra where ecology meets economy. Agroforestry Systems 6:12-13.

De Foresta, H. 2008. Forêts et foresteries dans les régions tropicales. Pages 138-155 in F. Hallé and P. Lieutaghi, editors. Aux origines des plantes. Fayard, Paris, France.

De Koninck, R. 2005. L'Asie du Sud-Est. Armand Colin, Paris, France.

Dove, M. R. 1993. Smallholder rubber and swidden agriculture in Borneo: a sustainable adaptation to the ecology and economy of the tropical forest. Economic Botany 47:136-147.

Dudley, R. G. 2000. The rotten mango: the effect of corruption on international development projects. Part 1: Building a system dynamics basis for examining corruption. System Dynamics Society, Bergen, Norway. 
Eder, J. F. 2006. Land use and economic change in the post-frontier upland Philippines. Land Degradation \& Development 17:149-158.

Ekadinata, A., and G. Vincent. 2010. Rubber agroforests in a changing landscape: analysis of land use/cover trajectories in Bungo district, Indonesia. Forests, Trees and Livelihoods 20(1):in press.

Erasmi, S., and J. A. Priess. 2007. Satellite and survey data: a multiple source approach to study regional land-cover/land-use change in Indonesia. F. Dickmann, editor. Geovisualisation in Human Geography. Kartographische Schriften 13:101114.

Feintrenie, L., W. K. Chong, and P. Levang. 2010. Why do farmers prefer oil palm? Lessons learnt from Bungo district, Indonesia. Small-scale Forestry 9(3):379-396.

Feintrenie, L., and P. Levang. 2009. Sumatra's rubber agroforests: advent, rise and fall of a sustainable cropping system. Small-scale Forestry 8(3):323-335.

Feintrenie, L., and P. Levang. 2010. Local voices call for economic development over forest conservation: trade-offs and policy in Bungo, Sumatra. Forests, Trees and Livelihoods 20(1):in press.

Feintrenie, L., and E. Martini. 2010. Public development programs influence on Bungo District landscape and people's futures. In C. J. P. Colfer and J. L. Pfund, editors. Collaborative Governance of Tropical Landscapes. Earthscan, London, UK, in press.

Gadgil, M., P. Olsson, F. Berkes, and C. Folke. 2003. Exploring the role of local ecological knowledge for ecosystem management: three case studies. Pages 189-209 in F. Berkes, J. Colding, and C. Folke, editors. Navigating social-ecological systems: building resilience for complexity and change. Cambridge University Press, Cambridge, UK.

Garcia, C.A., S. Bhagwat, J. Ghazoul, C.D. Nath, K. M. Nanaya, C. G. Kushalappa, Y. Raghuramulu, R. Nasi, and P. Vaast. 2010. Biodiversity conservation in agricultural landscapes: challenges and opportunities of coffee agroforests in the Western Ghats, India. Conservation Biology 24:479-488.

Hughes, D. M. 2001. Cadastral politics: the making of community-based resource management in Zimbabwe and Mozambique. Development and Change 32(4):741-768.

Huxley, P. A. 1999. Tropical agroforestry. Blackwell Science, London, UK.

Index Mundi. 2010. [online] URL: http://www.ind exmundi.com/.

Joshi, L., G. Wibawa, G. Vincent, D. Boutin, R. Akiefnawati, M. G. Gerhard, M. Van Noordwijck, and S. Williams. 2002. Jungle rubber: a traditional agroforestry system under pressure. ICRAF, Bogor, Indonesia.

Juhrbandt, J., T. Duwe, J. Barkmann, G. Gerold, and R. Marggraf. 2010. Structure and management of cocoa agroforestry systems in Central Sulawesi across an intensification gradient. Pages 351-376 in T. Tscharntke, C. Leuschner, E. Veldkamp, H. Faust, E. Guhardja, and A. Bidin, editors. Tropical rainforests and agroforests under global change. Springer, Berlin, Germany.

Keesler, J. J., T. Rood, T. Tekelenburg, and M. Bakkenes. 2007. Biodiversity and socioeconomic impacts of selected agro-commodity production systems. The Journal of Environment \& Development 16:131-160.

Koh L. P., P. Levang, and J. Ghazoul. 2009. Designer landscapes for sustainable biofuels. Trends in Ecology and Evolution 24(8):431-438.

Komarudin, H., Y. L. Siagian, and C. J. P. Colfer, with Neldysavrino, Yentirizal, Syamsuddin, and D. Irawan. 2008. Collective action to secure property rights for the poor: a case study in Jambi Province, Indonesia. CAPRi Working Paper 90. Collective Action and Property Rights SystemWide Initiative, Washington, D.C., USA.

Kusters, K. 2009. Non timber forest product trade - a trade-off between conservation and development. Dissertation. University of Amsterdam, The Netherlands. 
Kusters, K., M. Ruiz Pérez, H. de Foresta, T. Dietz, M. Ros-Tonen, B. Belcher, P. Manalu, A. Nawir, and E. Wollenberg. 2008. Will agroforets vanish? The case of damar agroforests in Indonesia. Human Ecology 36(3):357-370.

Legowo, T. A., and M. Takahashi, editors. 2003. Regional autonomy and socio-economic development in Indonesia. A multidimensional analysis. Institute of Developing Economies, Japan External Trade Organization, Chiba, Japan.

Lehébel-Péron, A., L. Feintrenie, and P. Levang. 2010. Rubber agroforest profitability, the importance of secondary products. Forests, Trees and Livelihoods 20(1):in press.

Levang, P. 1994. Agroforestry as an ecodevelopment model: an interface between conservation and development. Pages 20-25 in D. Arnaud, H. Ilbert, and R. Mongruel, editors. Biodiversity: the coveted fruit. FPH-Solagral, Paris, France.

Levang, P. 1997. La terre d'en face. La transmigration en Indonésie. ORSTOM, Montpellier, France.

Levang, P., E. Dounias, and S. Sitorus. 2005. Out of the forest, out of poverty? Forests, Trees and Livelihoods 15:211-235.

Levang, P., D. Sheil, and M. Kanninen. 2008. Le palmier à huile, Dr Jekill pour l'énergie, Mr Hyde pour la biodiversité. Pages 26-31 in Biodiversité, énergie et changements climatiques: enjeux et perspectives - UICN Congrès Mondial de la Nature 2008, Barcelona, Spain. Liaison ÉnergieFrancophonie, Special issue, September 2008.

Levang, P., and S. Sitorus. 2006. Rubber smallholders versus acacia growers: socioeconomic survey of the Rambang Dangku subdistrict (South Sumatra). IRD/CIFOR, Bogor, Indonesia.

Maertens, M., M. Zeller, and R. Birner. 2006. Sustainable agricultural intensification in forest frontier areas. Agricultural Economics 34:197-206.

Mary, F. 1986. Agroforêts et sociétés. Étude comparative de trois systèmes agroforestiers indonésiens. Dissertation. ENSA, Montpellier, France.

McCarthy, J. 2007. Shifting resource entitlements and governance reform during the agrarian transition in Sumatra, Indonesia. Journal of Legal Pluralism 55:65-122.

McCarthy, J., and R. A. Cramb. 2009. Policy narratives, landholder engagement, and oil palm expansion on the Malaysian and Indonesian frontiers. Geographical Journal 175:112-123.

Michon, G. 1985. De l'homme de la forêt au paysan de l'arbre. Agroforesteries indonésiennes. Dissertation. Université des Sciences et Techniques du Languedoc, Montpellier, France.

Michon, G. 2005. Domesticating forests. How farmers manage forest resources. CIFOR/IRD/ ICRAF, Bogor, Indonesia.

Michon, G., H. De Foresta, P. Levang, and F. Verdeaux. 2007. Domestic forests: a new paradigm for integrating local communities' forestry into tropical forest science. Ecology and Society 12(2):1. [online] URL: http://www.ecologyandsociety.org/vol12/ iss2/art1/.

Nair, P. K. R. 1985. Classification of agroforestry systems. Agroforestry Systems 3:97-128.

Penot, E. 1995. Taking the jungle out of the rubber. Improving rubber in Indonesian agroforestry systems. Agroforestry Today 7(3-4):1-13.

Penot, E. 1998. L'amélioration des agroforêts à hévéa en Indonésie. Plantations, Recherche, Developpement 5(2):1-12.

Penot, E. 2000. Les agroforêts à hévéas améliorées en Indonésie: mythe ou réalité? Plantations, Recherche, Developpement 6(6):400-414.

Rasul, G., G. B. Thapa, and M.A. Zoebisch. 2004. Determinants of land-use changes in the Chittagong Hill Tracts of Bangladesh. Applied Geography $\mathbf{2 4}$ (3):217-240.

Reetz, S. W. H. 2008. Socioeconomic dynamics and land use change of rural communities in the vicinity of the Lore-Lindu National Park. STORMA Discussion Paper Series 28. Göttingen, Germany, 
and Bogor, Indonesia. [online] URL: http://webdoc. sub.gwdg.de/ebook/serien/yo/STORMA/SDP28.pdf

Rigg, J. 2006. Land, farming, livelihoods, and poverty: rethinking the links in the rural South. World Development 34(1):180-202.

Rist, L., L. Feintrenie, and P. Levang. 2010. The livelihood impacts of oil palm: smallholders in Indonesia. Biodiversity Conservation 19(4):10091024.

Ruf, F. 2001. Tree crops as deforestation and reforestation agents: the case of cocoa in Côte d'Ivoire and Sulawesi. Pages 291-315 in A. Angelsen and D. Kaimowitz, editors. Agricultural technologies and tropical deforestation. CAB International, Wallington, UK.

Ruf, F., and G. Schroth. 2004. Chocolate forests and monocultures: a historical review of cocoa growing and its conflicting role in tropical deforestation and forest conservation. Pages 107134 in G. Schroth, G. da Fonseca, C. Harvey, C. Gascon, H. Vasconcelos, and A. Izac, editors. Agroforestry and biodiversity conservation in tropical landscapes. Press Islands, Washington, D. C., USA.

Seeberg-Elverfeldt, C. 2008. Carbon finance schemes in Indonesia. Empirical evidence of their impact and institutional requirements. Dissertation. Georg-August-Universität Göttingen, Göttingen, Germany.

Seeberg-Elverfeldt, C. S. Schwarze, and M. Zeller. 2009. Carbon finance options for smallholders' agroforestry in Indonesia. International Journal of the Commons 3(1):108-130.

Shohibuddin, M. 2008. Discursive strategies and local power in the politics of natural resource management: the case of Toro village. Pages 91132 in G. Burkard and M. Fremerey, editors. A matter of mutual survival. Lit Verlag Dr. W. Hopf, Berlin, Germany.

Sturgeon, J. C. 2010. Governing minorities and development in Xishuangbanna, China: Akha and Dai rubber farmers as entrepreneurs. Geoforum 41 (2):318-328.
Suyanto, S. 2007. Underlying cause of fire: different form of land tenure conflicts in Sumatra. Mitigation and Adaptation Strategies for Global Change 12:67-74.

Therville, C. 2008. Rubber agroforests conversion in Bungo district (Jambi, Indonesia); perception survey and spatial analysis. Dissertation. University of Technology and Sciences/Montpellier II, Montpellier, France.

Therville, C., L. Feintrenie, and P. Levang. 2010. Farmers' perspectives about agroforests conversion to plantations in Sumatra. Lessons learnt from Bungo district (Jambi, Indonesia). Forests, Trees and Livelihoods 20(1):in press.

Torquebiau, E. 1992. Are tropical agroforestry home gardens sustainable? Agriculture, Ecosystems \& Environment 41:189-207.

Torquebiau, E. 2000. A renewed perspective on agroforestry concepts and classification. Compte rendu de l'Académie des Sciences / Editions Scientifiques et Techniques Elsevier SAS 323:10091017.

Van Noordwick, M., T. Tomich, D. Garrity, and A. Fagi, editors. 1995. Alternatives to slash and burn in Indonesia. ASB 1995 Conference Proceedings, Bogor. ICRAF, Bogor, Indonesia.

Weber, R. 2006. Kulturlandschaftswandel in Zentralsulawesi: historisch-geographische Analyse einer indonesischen Bergregenwaldregion.

Universitätsverlag Göttingen, Göttingen, Germany. [online] URL: http://webdoc.sub.gwdg.de/univerla g/2006/pf12.pdf.

Wells, A. 2008. Verification of legal compliance in Indonesia. Pages 173-186 in D. Brown, K. Schreckenberg, N. Bird, P. Cerutti, F. D. Gatto, C. Diaw, T. Fomété, C. Luttrell, G. Navarro, R. Oberndorf, H. Thiel, and A. Wells, editors. Legal timber: verification and governance in the forest sector. CATIE/RECOFTC/CIFOR/ODI, London, UK. 